\title{
Ba-Pb MINERALIZATION IN UGWUAJIRIJA ISHIAGU AREA, LOWER BENUE TROUGH, SOUTHEASTERN NIGERIA: GEOCHEMICAL EVIDENCE
}

YOUNG EZENWA OBIOHA

(Received 12 June 2018; Revision Accepted 22 June 2018)

\begin{abstract}
Study of rocks of Ugwuajirija Ishiagu area was carried out to determine their mineralization characteristics. This involved 38 samples and elemental ratios, including $\mathrm{Ba}, \mathrm{Be}, \mathrm{Co}, \mathrm{Cu}, \mathrm{Cs}, \mathrm{Nb}, \mathrm{Ni}, \mathrm{Pb}, \mathrm{Sr}, \mathrm{Y}, \mathrm{Zn}$ and $\mathrm{Ba} / \mathrm{K}_{2} \mathrm{O}, \mathrm{Ba} / \mathrm{Ni}$ using ICP-MS and ICP-AES techniques. Geological mapping reveals that the area is underlain by four lithostratigraphic formations: Asu River group, Eze-Aku Shale, Nkporo Shale and Mamu Formation. The preSantonian formations were affected by magmatic intrusion and emplacement of dolerites, diorites and other diabasic rocks, and hydrothermal solutions leading to mineralization of economic mineral deposits. Modal analysis reveals the dolerite has average plagioclase concentration (41\%), ortho-pyroxene (29\%), clino-pyroxene (7\%), and olivine $(9$ $\%)$. Marly mudstone has quartz (10\%), plagioclase (25\%), orthopyroxene $(20 \%)$, clino-pyroxene $(8 \%)$ and olivine (8\%). Trace and rare earth element analytical results show that all the analyzed samples were depleted in $\mathrm{Cs}, \mathrm{Sn}$, and $\mathrm{Be}<1.0 \mathrm{ppm}$, but enriched in Ba- 802ppm through $936 \mathrm{ppm}$ in the dolerite, to $>10,000 \mathrm{ppm}$ in the marly-mudstone respectively, which are 2 to 100 times above the average crustal abundance of Ba- $400 \mathrm{ppm}$. The mean concentration of $\mathrm{Cu}, \mathrm{Pb}$, and $\mathrm{Zn}$ increased from 66.2 to $94 \mathrm{ppm}$ in the dolerite at Ugwuele, to $1049 \mathrm{ppm}$ in the marly-limestone, to $>10,000 \mathrm{ppm}$ in the ferruginized mudstones at Ugwuajirija respectively. These enrichments which are above average crustal abundance show that the mudstone and marly limestone in Ugwuajirija Ishiagu area are $\mathrm{Ba}$ and $\mathrm{Pb}$ mineralized. Further exploration and exploitation are recommended for effective youth empowerment and national development.
\end{abstract}

KEYWORDS: Ba-Pb Mineralization, Ugwuajirija, Lower Benue Trough, Trace Element

\section{INTRODUCTION}

Ugwuajirija is a part of Ishiagu area, located in the sedimentary basin of Southeastern Nigeria (Fig, 1), and forms part of the Afikpo Basin in the Lower Benue Trough. The Benue Trough is a NE -SW trending structure, stretching over $800 \mathrm{~km}$ from the Niger Delta in the south to Chad Basin in the North, with a width of $400 \mathrm{~km}-600 \mathrm{~km}$ in places (Benkhelil, 1987). It harbors clastic sediments varying from $\sim 450 \mathrm{~km}$ to $800 \mathrm{~km}$ depth range in places (Benkhelil, 1987; 1982). The trough received sedimentation of the Asu River Group during the Albian period, followed by the Eze-Aku Shale, which was unconformably overlain by Mamu formations during the Campanian- Maastricthian times of the Cretaceous Period (Reyment, 1967). During the Santonian orogeny, which affected the earth globally including Nigeria, tectonic uplift, deformation and magmatism resulted in faulting, folding and other fractural features. These features thus, created favourable environment for intrusion of intermediate to basic magma, and emplacement of dolerites, dioritic and pegmatitic igneous rocks, generation of hydrothermal solutions and mineralization of sphalerite, bornite, galena, pyrite, hematite, and magnetite etc. in the area (Ofor, 1997). Though some work had been published on mineral potentials and occurrence in the area (Ofor, 1997), more work is still needed to properly and systematically define the rocks and economic mineral characteristics of the area. This work uses petrography, major and trace elements occurrences and characteristics of the rocks to unravel the $\mathrm{Ba}-\mathrm{Pb}-\mathrm{Zn}$ mineralization and economic potentials in the Ugwuajirija area Ishiagu Lower Benue Trough.

\subsection{Location of Study Area}

Ugwuajirija is a part of Ishiagu in the present Ebonyi State of Nigeria. It is located within latitudes $5^{\circ} 49^{\prime}$ to $6^{\circ} 00^{\prime} \mathrm{N}$ and longitudes $7^{\circ} 30^{\prime}$ to $7^{\circ} 40^{\prime} \mathrm{E}$ (Fig. 1). It is bounded in the north by Awgu in Enugu State, in the west by Lokpa-Lekwesi in Abia State, in the south by Obinago and in the east by Aka-Eze in Ebonyi State. It covers an area of about $672.22 \mathrm{~km}^{2}$.

Young Ezenwa Obioha, Department of Geology, School of Physical Sciences, Federal University of Technology Owerri, Nigeria 


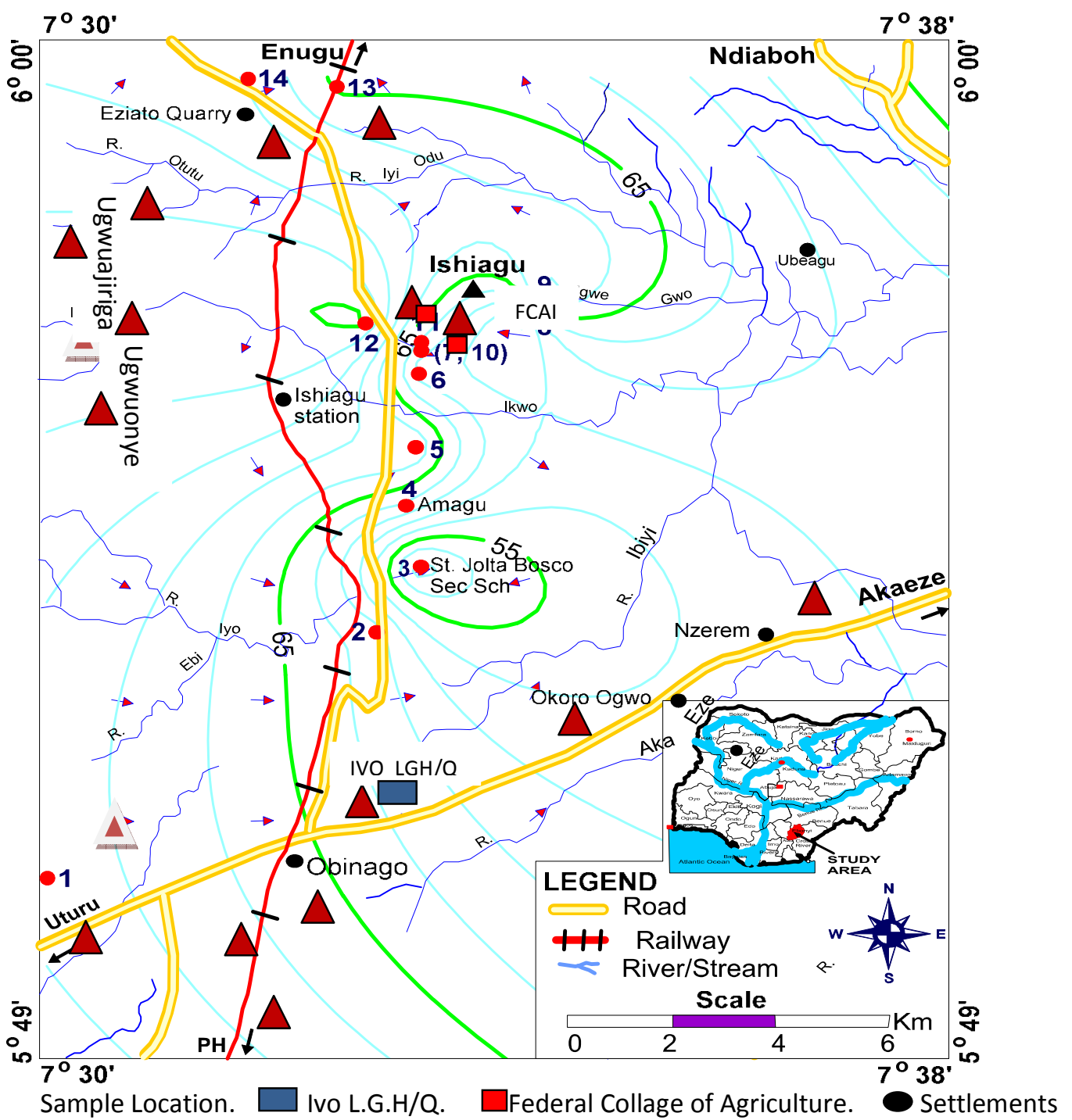

Fig. 1: Sample location map of the Study area showing drainage. Inset: Map of Nigeria showing location of the study area.

It experiences two seasons -dry November to March and rainy March to October each year (Udo, 1970). The average annual temperature is about $27^{\circ} \mathrm{C}$ to $30^{\circ} \mathrm{C}$ with average rainfall of about 1200in to 20000in. The inhabitants engage in moderate agricultural activities in the area. The vegetation is the Savanna. The area can be accessed by the Awgu-Ishiagu-Ivo roads and Okigwe-Ivo- Afikpo roads. Fig.2 is the geological map of the area, and Table 1 summarizes the stratigraphy of the area. 


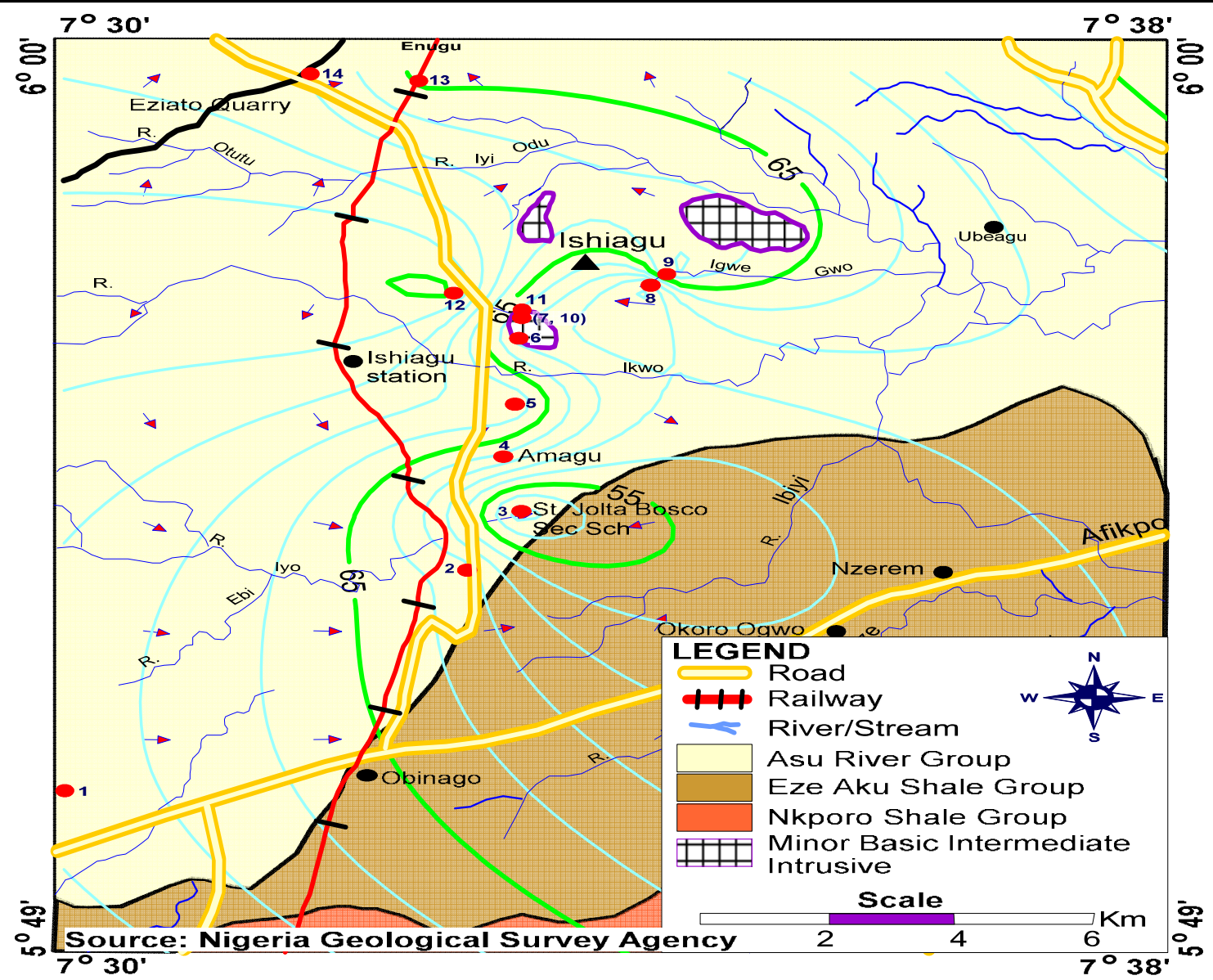

Fig. 2: Geological Map of study area

Table 1: Lithostratigraphy of Study Area (Ugwuajirija Ishiagu area Lower Benue Trough, Southeastern Nigeria)

\begin{tabular}{|c|c|c|c|c|c|}
\hline Period & Period & Formation & Lithology & Environment & $\begin{array}{l}\text { Cycle of } \\
\text { Sedimentation }\end{array}$ \\
\hline $\begin{array}{l}\text { C } \\
\mathbf{R} \\
\mathrm{E}\end{array}$ & $\begin{array}{l}\text { Campanian- } \\
\text { Maastricthian }\end{array}$ & $\begin{array}{l}\text { Nsukka } \\
\text { Ajali } \\
\text { Mamu }\end{array}$ & $\begin{array}{l}\text { Sandstone, Shale, } \\
\text { Coal Seam, } \\
\text { Clay,Limestoness }\end{array}$ & $\begin{array}{l}\text { Regressive; } \\
\text { Fluvial-Deltaic }\end{array}$ & $3^{\text {rd }}$ Cycle $^{*}$ \\
\hline $\begin{array}{l}\mathrm{T} \\
\mathrm{A}\end{array}$ & $\begin{array}{l}\text { Santonian- } \\
\text { Coniacian }\end{array}$ & |IIIIIIIIIIIIIIIIII & ||IIIIIIIIIIIIIIIIIIIIIIIII & ||IIIIIIIIIIIIIIIIIIIII & \multirow[t]{2}{*}{$2^{\text {rd }}$ Cycle $^{*}$} \\
\hline $\begin{array}{l}\mathrm{C} \\
\mathrm{E}\end{array}$ & $\begin{array}{l}\text { Turonian- } \\
\text { Cenomanian }\end{array}$ & $\begin{array}{l}\text { Eze-Aku } \\
\text { Shale }\end{array}$ & $\begin{array}{l}\text { Shale, Sandstone, } \\
\text { Coal Seam, Clay }\end{array}$ & $\begin{array}{l}\text { Transgressive } \\
\text { Marine }\end{array}$ & \\
\hline $\begin{array}{l}0 \\
U\end{array}$ & Albian & $\begin{array}{ll}\text { ASU } & \text { River } \\
\text { Group (ARG) }\end{array}$ & $\begin{array}{l}\text { Sandstone, Shale, } \\
\text { Limestone, Clay }\end{array}$ & Regressive & $1^{\text {st }}$. .Cycle ${ }^{*}$ \\
\hline
\end{tabular}

Key: *After Gideon et al, 2014.

\section{$2.0 \quad$ GEOLOGICAL SETTING}

The area of study lies within the Afikpo Basin in the Lower Benue Trough of Southeastern Nigeria Sedimentary basin. The Lithostratigraphic sequence comprises of the Asu River Group (ARG) -Albian the Oldest litho-sequence which unconformably overlies the basement complex. This is overlain by the Eze-Aku Formation-Turonian, unconformably juxtaposed by the Mamu Formation-Campanian/Maastrichtian (Table 1), (Reyment, 1965, 1967). The disappearance of the Awgu and Nkporo Formations in the area corroborates the occurrence of unconformity. According to Kogbe (1976), the area must have suffered non-deposition, weathering and/or erosion, which led to the juxtaposition of the stratigraphically younger Mamu Formation on the superior Eze-Aku Shale.

The lithology of these formations consists of shale, sandstone, limestone/carbonate and clay, with coal seams measuring between 1.2 to $2.5 \mathrm{~m}$ thickness, occurrences in the Mamu Formation, based on which the Mamu Formation was formally call Lower Coal Measures (Reyment, 1967). The Pre-Santonian sediments had been intruded by basic to intermediate magmas resulting in the emplacement of igneous rocks mainly dolerites, diorites and other diabasic rocks. That 
intrusion created faults, folds, joints and other deformational structures and caused metamorphism and these favoured the mineralization of economic mineral deposits of barite, galena, sphalerite and bornite
(Ekwueme,1993a; Ofor, 1997). The field relationships and structures of various outcrops are shown in Figs. 3 A - B. The photomicrographs of the various rock outcrops in the area are shown as Figs (4 and 5).
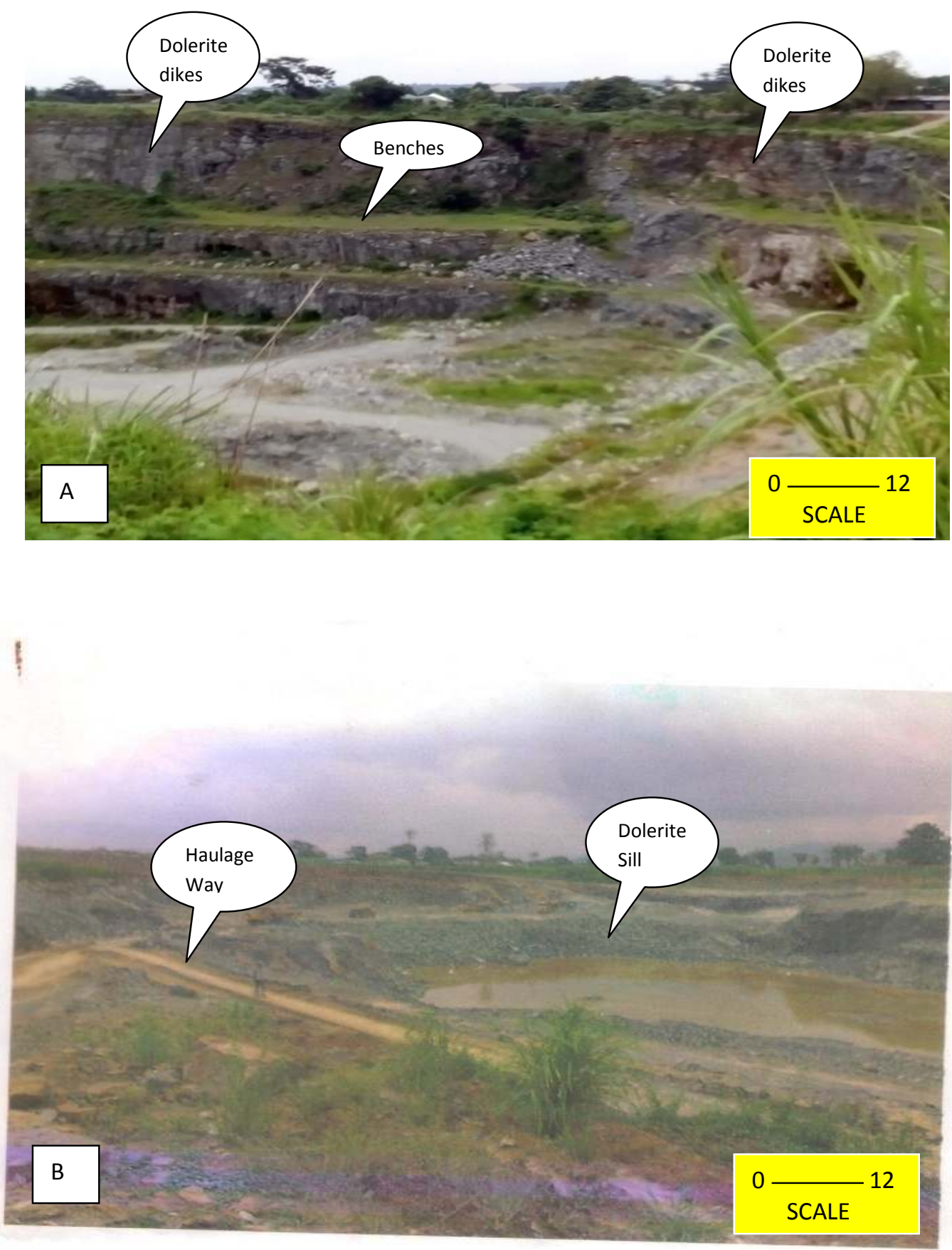

Fig. 3 A and B: Litho-structural field relations of the Ugwuajirija rock outcrop, Ishiagu. Lower Benue Trough SE. Nigeria. (A). Dolerite dikes outcrop at the raw materials excavation source pit, Crush Rock Quarry Ishiagu, displaying disconformal structural relationship. (B). Dolerite sills outcrop overlying diorite, at the Crush Rock raw materials source pit (Open Cast Quarry), 

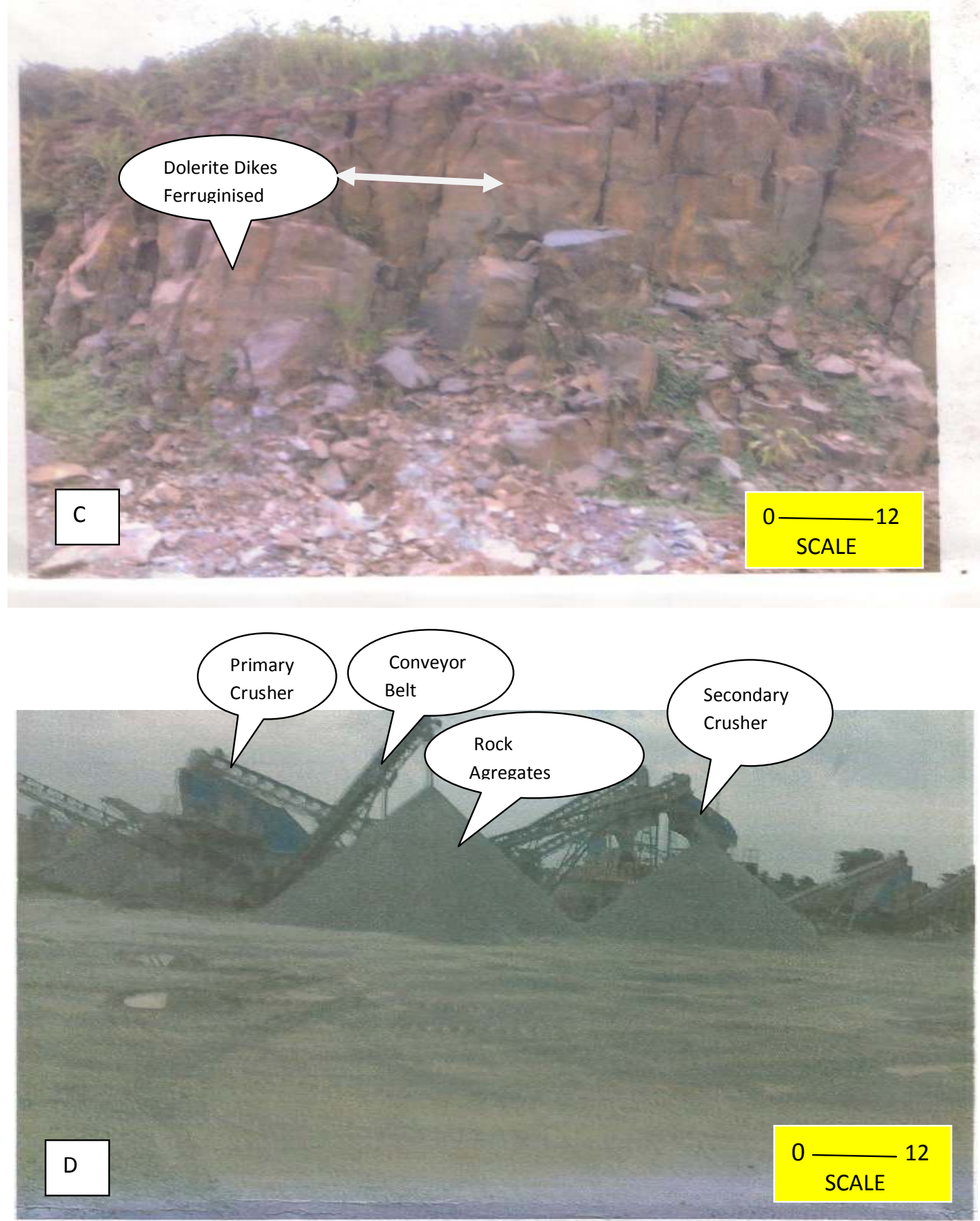

Fig. 3 C and D: Litho-structural field relations of the Ugwuajirija rock outcrop, Ishiagu. Lower Benue Trough SE. Nigeria. (C). Dolerite dikes outcrop at the raw materials excavation source pit, Setraco Quarry Ugwuele displaying disconformal structural relationship. (D). Setraco Rock Crushing Plants (Ugwuele, Ishiagu Area).

\subsection{METHODS OF STUDY}

The study involved field geological mapping and laboratory studies. The laboratory study consisted of thin section petrography and whole-rock geochemical analysis. The procedures were based on the method after Obioha et al, (2013).

\subsection{Petrographic Analysis}

The thin sections of the rock samples were made at the University of Calabar, Engineering Geological Workshop. The optimum diameter of $0.03 \mathrm{~mm}$ was censured by continuous microscopic cross-viewing the mounting slide. The lithological, mineralogical, textural 
and structural characteristics of the rocks were determined based on the method after Obioha and Ekwueme (2011) and representative photomicrographs (Figs. 4 \& 5 A-D) were presented.

\subsection{Whole Rock Geochemistry}

The geochemistry study involved whole rock geochemical analyses of 35 representative rock samples from the study area. The analytical technique was the G4A-G4B; the digestive media were Li-borate and Li-tetraborate, followed by $\mathrm{HCl}$ dilution. The analytical procedures were the ICP-MS and the ICP-
AES, carried out at the Acme Mineral/Geochemical Analytical Laboratory, Vancouver, Canada. The cutting, crushing, pulverization and weighing were done by special electronic handling (SEH). The resolution was $0.001 \mathrm{ppm}$ for the trace and rare earth elements (REE), and $100 \%$ for the major elements. The analytical techniques were based on the methods after Skoog and West (!978), Ekwueme (1993b, 1994), Ofulume (2009) and Obioha, (2014). Photomicrographs of representative samples showing the mineral composition of the rocks are presented in Figs. 4 and 5.

Table 2: Average modal composition (vol. \%) of rocks of Ishiagu area, Lower Benue Trough, Nigeria

\begin{tabular}{|l|l|l|l|l|c|}
\hline Minerals & $\begin{array}{l}\text { D1.L1; } \\
\text { X5 }\end{array}$ & D1.L2; X5 & B1.L3; X5 & DR.2.L4; X5 & MRL-MST \\
\hline Quartz & & & & 10 & 12 \\
\hline Orthoclase & & tr & & 22 & 10 \\
\hline Plagioclase & 42 & 40 & 20 & 38 & 23 \\
\hline Biotite & & & 7 & 6 & 6 \\
\hline Calcite & & & & & 25 \\
\hline Dolomite & & & & & 20 \\
\hline Ortho-Pyroxene & 28 & 30 & 40 & 12 & \\
\hline Clino-Pyroxene & 9 & 8 & 18 & 8 & \\
\hline Olivine & 10 & 8 & 6 & & \\
\hline Hornblende & & 2 & & & \\
\hline Opaques & 6 & 5 & 2 & 9 & 4 \\
\hline Accessories & 5 & 7 & 3 & 7 & 100 \\
\hline Total & 100 & 100 & 100 & 100 & \\
\hline
\end{tabular}

D1.L1 = Dolerite from Crush Rock mining pit Ishiagu.

D1.L2 = Dolerite sample from Setraco mining pit Ishiagu.

B1.L3 = Basalt sample from Ugwuele mining pit Ishiagu.

DR2.L4 = Diorite sample from Crush Rock Industries mining pit Ishiagu.

MRL-MST = MARLY Mudstone at Obinago

\subsection{RESULTS AND DISCUSSIONS}

The results of the modal analysis from the thin section petrography are shown in Table 2 . The results of the whole rock geochemical analyses of the major elements are presented in Table 3. Table 2 shows that four main rock types: dolerite, basalt and diorites and marl occur in the area. Five (5) representative rock samples were collected from each of these outcrops and specimen thin sections prepared. The modal analysis (Table 2), shows that the dolerite (samples D1.L1 and D1.L2) consists mainly of plagioclase (An-30-70) in the andesine to bywtonite range, 40 to 42 average volume $\%$, ortho-pyroxene 28 to 30 vol. \% average, clinopyroxene 8 to 9 vol. \% average, olivine 8 to $10 \mathrm{vol}$. \% average. Opaques and accessories constitute the rest of the modal volume. These rocks show geochemical signature of basic magma of intermediate character (Grant, 1969). The basalt (samples B1.L3), consists of orho-pyroxene 40 vol. \%, clino-pyroxene 8 vol. \%, plagioclase $20 \mathrm{vol}$. \% and olivine (6vol. \%). Opaques and accessories constitute the rest of the modal volume. These properties show that the dolerites and basalts were derived from basaltic magma of tholeitic composition (Ekwueme, 2003; 2010). The diorite consists of quartz (10 vol. \%), plagioclase $38 \mathrm{vol}$. \%, orthoclase 22 vol. \%, orho-pyroxene 12 vol. \%, clinopyroxene 8 vol. \%. Opaques and accessories constitute the rest of the modal volume. The modal analysis results agree with the field geological results (Figs. $3 A-C$ ). 

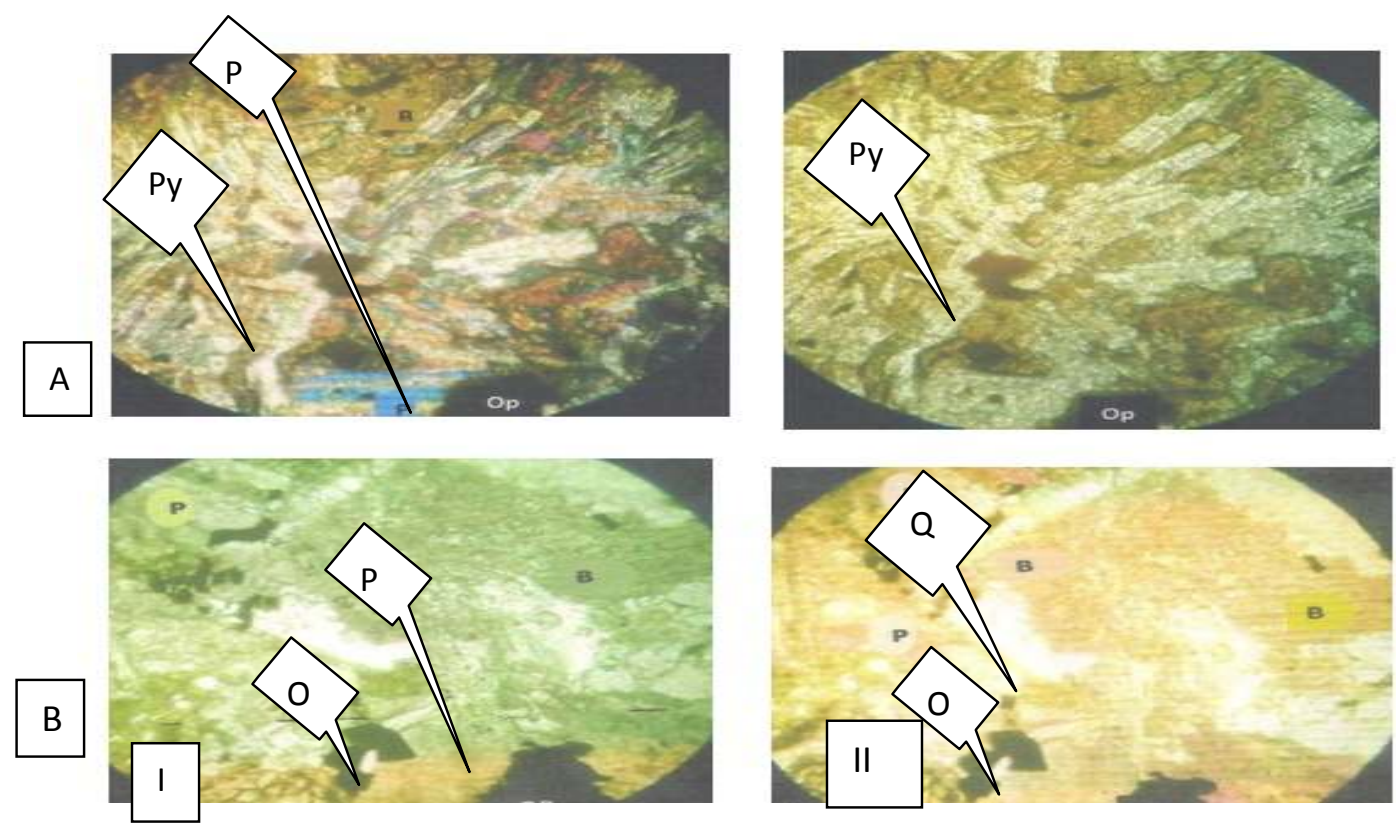

Fig. 4: Photomicrograph of rocks of Ugwuajirija area, Lower Benue Trough Nigeria. (A). Dolerite, showing laths of Plagioclase (P), pyroxene blades (Py), olivine (O): (I) XPL x20; (II) PPL x20

(B). Diorite showing plagioclase (P), pyroxene (Py), and quartz (Q): (I) XPL x20; (II) PPL x20
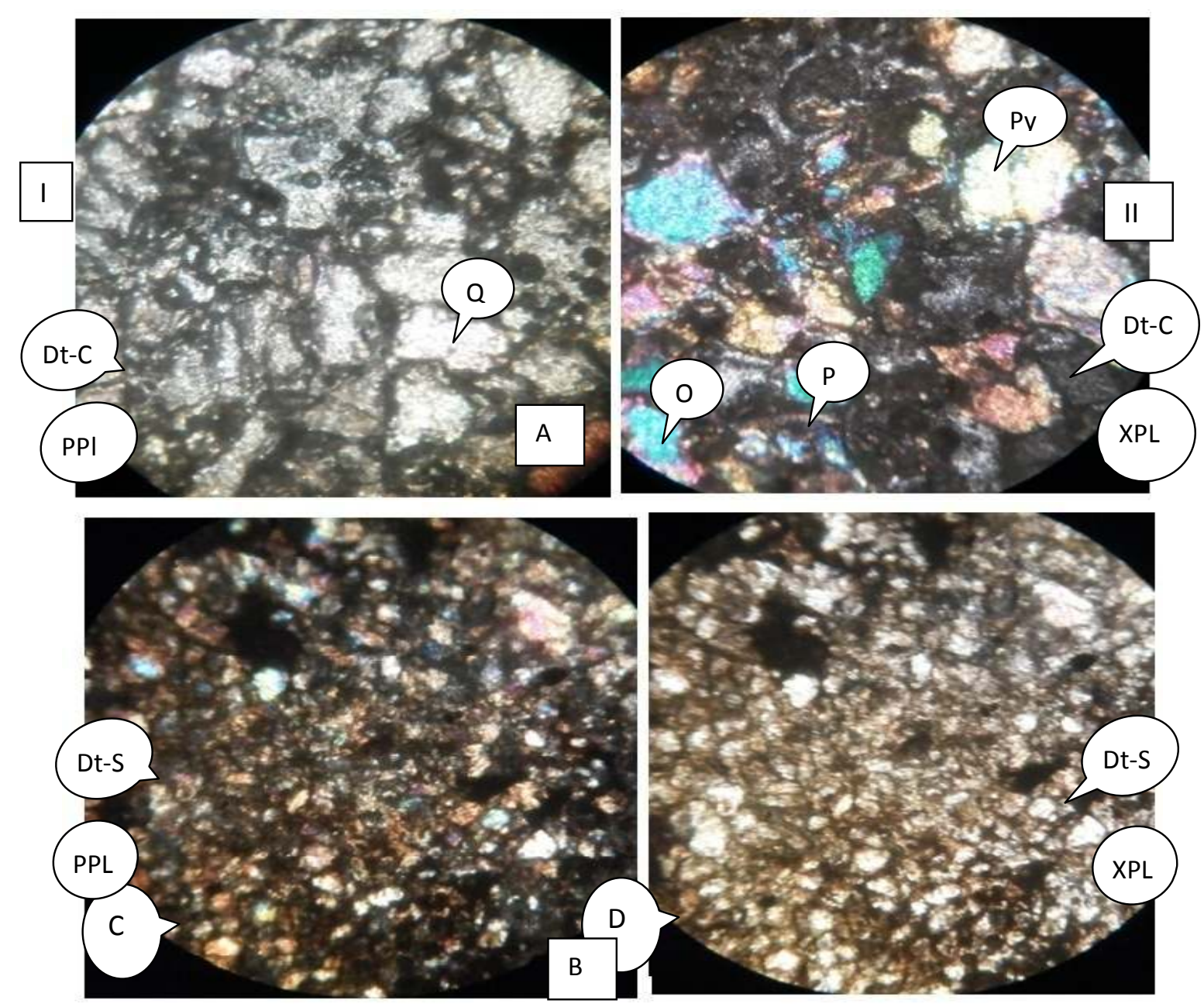

Fig. 5: Photomicrograph of rocks of Ugwuajiija area, Lower Benue Trough Nigeria: (A). Dt-C = Dolerite from Crush Rock Quarry, showing laths of Plagioclase $(P)$, pyroxene blades $(P Y)$, and olivine (O). (B). Dt-S = Dolerite from Setraco Quarry, showing plagioclase (P), pyroxene (Py), and quartz (Q), (I) XPL x20; (II) PPL x20. 


\subsection{Geochemical Results}

Table 3 shows that the $\mathrm{SiO}_{2}$ concentration ranges from $46.52 \mathrm{wt}$ \% (D1.L1) to $47.27 \mathrm{wt}$ \% (D1.L3), indicating that the dolerites are of basic composition derived from basaltic magma of tholeitic character. Sample D3.L2 (diorite) from Crush Rock quarry Ishiagu has $\mathrm{SiO}_{2}$ concentration of $57.21 \mathrm{wt}$ \% showing that this rock was derived from magma of intermediate composition. The $\mathrm{Al}_{2} \mathrm{O}_{3}$ concentration is high ranging from $12.95 \mathrm{wt}$ \% in the diorite (D3.L2) through $13.60 \mathrm{wt}$.
$\%$ (D1.L4) to $15.80 \mathrm{wt}$ \% in the dolerite. The granitic sample from Crush Rock Quarry has $\mathrm{Al}_{2} \mathrm{O}_{3}$ content of 7.19 wt. \% (Table 3 ). The alkalis content is 5.68 wt. \% average in the diorite, and ranges from $3.83 \mathrm{wt}$ \% to 4.95 wt. $\%$ in the dolerites, with a fairly constant low average value of $0.006 \mathrm{wt} \%$ in the granitic sample (D2.L1). This is contrary to the expected high value of alkalis in granitic rock. This low value must have been as a result of hydrothermal alteration leading to removal of $\mathrm{Na}+$ and $\mathrm{K}+$ ions from the feldspar.

Table 3: Geochemical result of major elements composition (wt. \%) rocks of Ugwuajirija Ishiagu area, Lower Benue

Trough, Nigeria

\begin{tabular}{|c|c|c|c|c|c|c|c|}
\hline Oxide & D1.L1 & D1.L2 & D1.L3 & D1.L4 & D1.L5 & D2.L1 & D3.L2 \\
\hline $\mathrm{SiO}_{2}$ & 46.52 & 47.17 & 47.24 & 47.27 & 47.20 & 67.9 & 57.21 \\
\hline $\mathrm{Al}_{2} \mathrm{O}_{3}$ & 15.42 & 17.00 & 14.17 & 13.60 & 15.80 & 7.19 & 12.95 \\
\hline $\mathrm{Fe}_{2} \mathrm{O} 3$ & 9.32 & 8.96 & 9.32 & 17.20 & 11.2 & 15.58 & 12.16 \\
\hline $\mathrm{CaO}$ & 13.07 & 8.23 & 9.72 & 7.39 & 10.10 & 0.02 & 4.41 \\
\hline $\mathrm{MgO}$ & 8.57 & 6.86 & 6.86 & 5.71 & 7.00 & 0.03 & 1.10 \\
\hline $\mathrm{MnO}$ & 0.62 & 0.44 & 0.66 & 0.68 & 0.60 & 0.04 & 0.15 \\
\hline $\mathrm{Na}_{2} \mathrm{O}$ & 3.86 & 3.14 & 3.38 & 2.42 & 3.20 & 0.01 & 2.58 \\
\hline $\mathrm{K}_{2} \mathrm{O}$ & 1.09 & 1.60 & 1.50 & 1.41 & 1.40 & 0.05 & 3.10 \\
\hline $\mathrm{P}_{2} \mathrm{O}_{5}$ & 0.48 & 0.42 & 0.53 & 0.48 & 0.48 & 0.04 & 0.51 \\
\hline $\mathrm{TiO}_{2}$ & 2.40 & 2.40 & 2.41 & 2.42 & 2.41 & 0.27 & 1.46 \\
\hline $\mathrm{Cr}_{2} \mathrm{O}_{5}$ & & & & & & 0.033 & 0.002 \\
\hline LOI & 0.25 & 3.14 & 3.14 & 0.66 & - & 6.7 & 3.8 \\
\hline Total & 100.69 & 99.36 & 101.69 & 99.22 & 99.94 & 99.95 & 99.96 \\
\hline Remarks & $\begin{array}{l}\text { Bluish } \\
\text { Unaltered } \\
\text { sample }\end{array}$ & $\begin{array}{l}\text { Redish } \\
\text { slighthly } \\
\text { altered }\end{array}$ & $\begin{array}{l}\text { Yellow } \\
\text { intensely } \\
\text { altered }\end{array}$ & $\begin{array}{l}\text { Yellow } \\
\text { intermediate } \\
\text { Altered }\end{array}$ & & & \\
\hline
\end{tabular}

Table 4: Average result of Trace elements composition (ppm) of rocks of Ugwuajirija. Ishiagu area, Lower Benue

\begin{tabular}{|c|c|c|c|c|}
\hline \multirow[b]{2}{*}{ Trace Elements } & \multicolumn{4}{|l|}{ LOCATION } \\
\hline & L1 x8 & L2 x8 & L3 x8 & L4 x8 \\
\hline $\mathrm{Cu}$ & 6.00 & $<5$ & 19.00 & 25 \\
\hline $\mathrm{Ba}$ & $>50,000$ & $>50,000$ & 18125 & 2677 \\
\hline $\mathrm{Zn}$ & 56 & 35 & 6.0 & 192 \\
\hline $\mathrm{Ni}$ & $<20$ & $<20$ & $<20$ & $<20$ \\
\hline Co & $<20$ & $<20$ & $<20$ & $<20$ \\
\hline $\mathrm{Sr}$ & 6002 & 12,578 & 455 & 360 \\
\hline $\mathrm{Zr}$ & $<5$ & $<5$ & 236 & 571 \\
\hline $\mathrm{Ce}$ & $<30$ & $<30$ & 60 & 158 \\
\hline $\mathrm{Y}$ & $<3$ & $<3$ & 6 & 67 \\
\hline $\mathrm{Nb}$ & $<5$ & 27 & 14 & 43 \\
\hline Sc & $<1$ & $<1$ & 8 & 20 \\
\hline $\mathrm{Pb}$ & $>10,000$ & $>10,000$ & 1500 & 2500 \\
\hline $\mathrm{Ba} / \mathrm{K}_{2} \mathrm{O}$ & 45879 & 31250 & 5410 & 1899 \\
\hline $\mathrm{Ba} / \mathrm{Na}_{2} \mathrm{O}$ & 12953 & 15923 & 5362 & 1195 \\
\hline $\mathrm{Ba} / \mathrm{Ni}$ & 2500 & 2500 & 906 & 134 \\
\hline TOC/C (\%) & 0.55 & 0.68 Ugwuajirija. & 0.45 & 1.12 \\
\hline TOC/S (\%) & 13.82 & 13.54 & 0.12 & 0.10 \\
\hline
\end{tabular}

KEY: L1 = Marly mudstone from Obinago. L2 = Ferruginized Mudstone from Ugwuajirija.

L3 = Diorite Sample from Ugwuele. L4 = Dolerite sample from

\subsection{Trace Elements}

Trace and REE result shows that all the analyzed samples were depleted in $\mathrm{Cs}, \mathrm{Sn}$, and $\mathrm{Be}<$ $1.0 \mathrm{ppm}$, below the average crustal abundance, except one sample that has Be concentration of 2.0ppm. The mudstone (MRL-MST at Obinago) has Ba concentration of $802 \mathrm{ppm}$ and $936 \mathrm{ppm}$ respectively, which are > x2 above the average crustal abundance of $\mathrm{Ba} 400 \mathrm{ppm}$. 
The trace elements concentration in the rocks vary, except $\mathrm{Ni}$ and $\mathrm{Co}$, which has constant concentration of 20 ppm. The $\mathrm{Cu}$ concentration varies from 5 ppm (L2) through $6 \mathrm{ppm}$ (L1) to maximum value of $25 \mathrm{ppm}$ (L4, Table 3). The Ce varies from $30 \mathrm{ppm}$ through $236 \mathrm{ppm}$ to maximum enrichment of $571 \mathrm{ppm}$ (Table 3). The $\mathrm{Pb}$ contents in all the analyzed samples were high, ranging from $1500 \mathrm{ppm}$ in sample L3 through $2500 \mathrm{ppm}$ in sample $L 4$ to maximum enrichment of $>10,000 \mathrm{ppm}$ in samples L1 and L2 (Table 3). The Ba concentration increased from 2677 ppm in sample L4 from Crush Rock Quarry Ishiagu, through 18125 ppm in sample L3 from Ugwuele, to maximum concentration of. $>50,000 \mathrm{ppm}$ in samples L1 and L2 Obinagu and Ugwuajirija respectively (Table 3 ).

The $\mathrm{Sr}$ concentration showed significant variation and enrichment, ranging from $360 \mathrm{ppm}$ in sample L4 from Crush Rock Quarry pit at Ishiagu, through $455 \mathrm{ppm}$ in sample L3 from Ugwuele, to 6002 $\mathrm{ppm}$ in sample $\mathrm{L} 1$ from Obinago, to maximum concentration of $12,578 \mathrm{ppm}$ in sample L3 from Ugwuele. These are all above the crustal average of 400 ppm for Ba (Taylor, 1965; Taylor and McLennan, 1985) and Sr 245 ppm for rhyolites, 355ppm for basaltic rocks and 525 ppm for andesites (Ekwueme, 1993a). The Pb gives a multiplicity of 3 to about 100 times the crustal thresh level (Taylor, 1965), and Ba gives a multiplicity of 6.6 to 125 times the average crustal abundance. The $\mathrm{Zn}$ concentration rises from 6.0 ppm (sample L1), through 35 ppm (sample L3), 56 ppm (sample L2), to maximum of 192 ppm in (sample L4, Table 3). These data strongly shows mineralization of $\mathrm{Pb}, \mathrm{Ba}, \mathrm{Sr}$ and $\mathrm{Zn}$ in Ishiagu area of the Lower Benue Trough Southeastern Nigeria. Currently both $\mathrm{Pb}$ and $\mathrm{Zn}$ are being mined at Ugwuele, Ugwuonye and Ugwuajirija areas in Ishiagu, Lower Benue Trough on artisanal and small scale bases.

\section{CONCLUSION AND RECOMMENDATION}

The study of rocks of Ugwuajirija Ishiagu area southeastern Nigeria indicates mineralization of $\mathrm{Pb}, \mathrm{Ba}$, $\mathrm{Sr}$ and $\mathrm{Zn}$ in Ishiagu area with threshold of $>3$ to 100 times the average crustal abundance of Ba 400 ppm, (Taylor, 1965), Sr 355 ppm (Ekwueme, 1993a). These resources are currently being mined on artisanal and small scale levels in the area. Huge capital outlay by government and multinational investors is necessary for effective development of the resources which may secure employment for our teaming youth and revenue for domestic and national development.

\section{ACKNOWLEDGEMENT}

The management of the Federal University of Technology Owerri, Nigeria is acknowledged for financial support. All the staff of the Department of Geology Federal University of Technology are hereby acknowledged for their moral support.

\section{REFERENCES}

Benkhelil, J., 1982. Benue Trough and Benue Chain. Geological Magazine, 119, 155-168.

Benkhelil, J., 1987. Deformations, magmatism and metamorphism in the Cretaceous of the Lower
Benue Trough, Nigeria. In: P. Bowden and J. A. Kinnaird (eds.). African Geology Reviews, Geological Journal, 22, 467-493.

Ekwueme, B. N., 1993a. An Easy Approach to Igneous Petrology. University of Calabar Press. 217p.

Ekwueme, B. N., 1993b. An Easy Approach to Metamorphic Petrology. University of Calabar Press. 168p.

Ekwueme, B. N., 1994. Elementary Crystallography and Mineralogy, including Optics. University of Calabar Press, 1994, 290.

Ekwueme, B. N., 2003. Geochemistry of crystalline basement rocks, Southwest Ugep. University of Calabar Press, 135p.

Ekwueme, B. N., 2010. The Pan African Event of Southeastern Nigeria - A Review. Nigerian Mining and Geosciences Society, Calabar-2010, Abstract Vol.

Ephram, B. E and Ekwueme, B. N., 2005. Rare earth elementary geochemistry and protoliths of schists in Southeast Lokoja, central Nigeria. Global Journal of Geological Sciences, 3(1), p. 9-15.

Gideon, Y. B., Fatoye, F. B and Omada, J. I., 2014. Sedimentological characteristics and geochemistry of Ajali Sandstone exposed at Ofe-Jiji and environs, northern Anambra Basin Nigeria. Research Journal of Environmental and Earth Sciences 6(1): 110 - 17, 2014.

Grant, N. K., 1969. The Precambrian to Early Paleozoic Pan-African Orogeny in Ghana, Togo, Dahomey and Nigeria. Bulletin of the Geological Society of America, 80, $45-56$.

Kogbe, C. A., 1976. Geology of Nigeria. Elizabethan Publishing Co., Lagos, 436p.

Obioha, Y. E., 2014. Petrology and geochemistry of rocks of Northwest Obudu, Southeastern Nigeria. Unpublished Ph.D. Thesis University of Calabar, 2014, 212p.

Obioha, Y. E. and Ekwueme, B. N. 2011. Petrology and chemical composition of gneisses of Northwest Obudu Plateau, SE. Nigeria. Global Journal of Pure and Applied Sciences, 17 (2), 215 - 226.

Obioha, Y. E., Ekwueme, B. N and Ephraim, B. E., 2013. REE Geochemistry and Protoliths of Gneisses of Northwest Obudu Plateau Southeastern Nigeria. Colloquium of African Geology CAG24 Addis Ababa Ethiopia, Jan. 2013, Abstract Vol., p.48.

Ofor, O., 1997. The Mineral Wealth of Nigeria. Industrial publishing House (OIPH) Owerri. 129p.

Ofulume, A. B., 2009. Keys of Mineralogy. Dikes 
Memorial Bookshop Limited, Port Harcourt. 162p. Ekwueme, B. N. (1994). Elementary Crystallography and Mineralogy, including Optics. University of Calabar Press, 1994, 290p.

Reyment, R. A., 1965. Aspects of the Geology of Nigeria Ibadan: Ibadan University Press. 145p.

Reyment, R. A., 1967. Aspects of the Geology of Nigeria. The Stratigraphy of the Cretaceous and Cenozoic Deposits. Ibadan University Press. P. 1-181.

Skoog, D. A and West, D. M., 1975. Fundamentals of Analytical Chemistry. ${ }^{\text {rd }}$. edition. Holt-Saunders, 804p.

Taylor, S. R., 1965. The application of trace element data to problems in petrology: In L. Ahrens, F. Press, S. K. Runcorn and C. Urey. Physics \& Chemistry of the Earth. 6, 133-214.
Taylor, S. R and McLennan, S. M., 1985. The Continental crust. Its composition and evolution. Blackwell, Oxford 312p.

Udo, R. K., 1970. Geographical regions of Nigeria. London: Heinemann Publishers, 212p. 